\title{
HUBUNGAN DUKUNGAN KELUARGA DENGAN KEPATUHAN KUNJUNGAN ANC PADA IBU HAMIL TRIMESTER III
}

\author{
${ }^{1}$ Mila Syari \\ ${ }^{1}$ Institut Kesehatan Helvetia, Medan, Indonesia \\ email: milasyari@helvetia.ac.id
}

\section{Artikel history}

Dikirim, Februari $4^{\text {th }}, 2019$

Ditinjau, Februari $18^{\text {th }}, 2019$

Diterima, Juni $13^{\text {th }}, 2019$

\begin{abstract}
Pregnancy examination is very important for all pregnant women to know fetal growth and maternal health. Almost all pregnant women in Indonesia (95.4\%) have had a prenatal check up (K1) and a frequency of at least 4 times during their pregnancy (83.5\%). This study aims to determine the relationship of family support with the compliance in ANC visits of third trimester pregnant women. Methods: The type of this research is an analytical survey with a cross sectional approach. The populations were 126 people and the samples were 30 people that was done by accidental sampling technique, which is accidentally unplanned sampling. The measuring instrument used was a questionnaire using univariate, bivariate and multivariate data analysis. The results of the study of 30 majority pregnant women Support Family 16 people (53.3\%) with obedient ANC visits 12 people (40\%) and 4 non-compliant people (13.3\%). Statistical test results with Chi-Square test with a $95 \%$ confidence level with $\alpha=0.05$ that significant value of family support with the compliance of ANC visit in pregnant women with $P$ value (Sign) $0.030<0.05$ means that family support variables have a significant relationship with compliance with ANC visits. The conclusion of this study shows that there is a relationship of instrumental family support with the compliance of ANC visits in third trimester.
\end{abstract}

Keywords: Family Support, the Compliance of ANC Visit.

\begin{abstract}
ABSTRAK
Pemeriksaan kehamilan sangat penting dilakukan oleh semua ibu hamil untuk mengetahui pertumbuhan janin dan kesehatan ibu. Hampir seluruh ibu hamil di Indonesia $(95,4 \%)$ sudah melakukan pemeriksaan kehamilan (K1) dan frekuensi minimal 4 kali selama masa kehamilannya $(83,5 \%)$. Tujuan penelitian untuk mengetahui hubungan dukungan keluarga dengan kepatuhan kunjungan ANC pada Ibu Hamil Trimester III. Jenis penelitian ini adalah survei analitik dengan pendekatan metode cross sectional, populasi berjumlah 126 orang, sampel berjumlah 30 orang dilakukan dengan teknik accidental sampling yaitu pengambilan sampel yang secara kebetulan tanpa direncanakan. Alat ukur yang digunakan adalah kuesioner dengan menggunakan analisis data univariat, bivariat dan multivariat. Hasil penelitian, dari 30 orang ibu hamil mayoritas Dukungan Keluarga 16 orang $(53,3 \%)$ dengan yang patuh melakukan kunjungan ANC 12 orang (40\%) dan yang tidak patuh 4 orang $(13,3 \%)$. Hasil uji statistik dengan uji Chi-Square dengan tingkat kepercayaan 95\% dengan $\alpha=0,05$ bahwa nilai signifikan dukungan keluarga dengan kepatuhan kunjungan ANC pada ibu hamil yang nilai P value (Sign) $0,030<$ 0,05 artinya variabel dukungan keluarga mempunyai hubungan signifikan dengan kepatuhan kunjungan ANC. Penelitian ini menyimpulkan, ada Hubungan Dukungan Keluarga Instrumental dengan Kepatuhan Kunjungan ANC Pada Ibu Hamil Trimester III Di Rumah Bersalin Dina Kota Medan Tahun 2018.
\end{abstract}

Kata Kunci : Dukungan Keluarga, Kepatuhan Kunjungan ANC 


\section{PENDAHULUAN}

Kehamilan merupakan pengalaman yang sangat bermakna bagi perempuan, keluarga dan masyarakat. Perilaku ibu selama masa kehamilannya akan mempengaruhi kehamilannya. Wanita (ibu) menjadi pusat asuhan kebidanan dalam arti bahwa asuhan yang diberikan harus berdasarkan pada kebutuhan ibu. Asuhan yang diberikan hendaknya tidak hanya melibatkan ibu hamil saja melainkan juga keluarganya, sebab keluarga menjadi bagian integral/ tak terpisahkan dari ibu hamil. Selain itu, keluarga juga merupakan unit sosial dan dapat memberikan dukungan yang kuat. Pemeriksaan kehamilan merupakan pemeriksaan kesehatan yang dilakukan untuk memeriksakan keadaan ibu dan janin secara berkala yang diikuti dengan upaya koreksi terhadap penyimpangan yang ditemukan.

Menurut definisi World Health Organization (WHO), kematian ibu adalah kematian seorang wanita waktu hamil atau dalam 42 hari sesudah berakhirnya kehamilan oleh sebab apapun, terlepas dari tuanya kehamilan dan tindakan yang dilakukan untuk mengakhiri kehamilan. ${ }^{(1)}$

Dari data WHO tahun 2013, Angka Kematian Ibu (AKI) di Indonesia yang tertinggi di Negara Association of South East Asia Nations (ASEAN) yakni 190 per 100.000 Kelahiran Hidup. Angka Kematian Ibu (AKI) di Negara Malaysia 29 per Kelahiran Hidup, Singapura 6 per 100.000 Kelahiran Hidup, Thailand 26 per kelahiran hidup dan Vietnam 49 per Kelahiran Hidup. ${ }^{(2)}$

Program Sustainable Development Goals (SDGs) di Indonesia mengalami dua permasalahan yaitu tentang penyakit menular dan penyakit degeneratif. Ibu, bayi baru lahir dan kesehatan anak di seluruh dunia, sekitar 830 wanita meninggal setiap harinya karena komplikasi selama kehamilan atau persalinan pada tahun 2015 mengurangi rasio kematian ibu global dari 216 per 100.000 kelahiran hidup pada tahun 2015 menjadi lebih sedikit dari 70 per 100.000 kelahiran hidup. Pada tahun 2030 SDGs akan membutuhkan tingkat pengurangan tahunan global setidaknya 7,5\% yang lebih dari tiga kali lipat tahunan pengurangan yang dicapai antara 1990 dan 2015 sebagian besar kematian ibu dapat dicegah sesuai kebutuhan pentingnya untuk meningkatkan akses wanita keperawatan yang berkualitas. $^{(3)}$

Penurunan AKI di Indonesia terjadi sejak tahun 1991 sampai tahun 2007, yaitu dari 390 menjadi 228. Namun demikian, Survei Demografi dan Kesehatan Indonesia (SDKI) tahun 2012 menunjukkan peningkatan AKI yang signifikan yaitu menjadi 359 kematian ibu per 100.000 kelahiran hidup. AKI kembali menunjukkan penurunan menjadi 305 kematian ibu per 100.000 kelahiran hidup berdasarkan Survei Penduduk Antar Sensus (SUPAS) 2015. ${ }^{(4)}$

Berdasarkan laporan profil kesehatan kab/kota, ditinjau jumlah kematian ibu tahun 2016 dilaporkan tercatat sebanyak 239 kematian. Namun bila dikonversi, maka berdasarkan profil Kabupaten/Kota maka AKI Sumatera Utara adalah sebesar 85/100.000 kh. Sedangkan berdasarkan hasil Survey AKI \&AKB yang dilakukan oleh Dinas Kesehatan Provinsi Sumatera Utara dengan FKM-USU tahun 2010 menyebutkan bahwa AKI di Sumatera Utara adalah sebesar 268 per $100.000 \mathrm{kh}$. Dan untuk angka kematian ibu (AKI) di Kota Medan sendiri yaitu berjumlah 3 kematian ibu di tahun 2016. ${ }^{(5)}$

Penyebab langsung kematian ibu adalah perdarahan (28\%), eklamsia (13\%), aborsi yang tidak aman (11\%) dan infeksi (10\%). Penyebab tidak langsung kematian ibu seperti : rendahnya status gizi ibu hamil anemia (51\%) dan "4 terlalu" $(60,6 \%)$ yaitu : terlalu muda, terlalu tua, terlalu sering dan terlalu banyak dan 3 terlambat" yaitu : terlambat mengenali tanda bahaya dan mengambil keputusan, terlambat mencapai fasilitas kesehatan dan terlambat mendapatkan pertolongan di fasilitas kesehatan. ${ }^{(6)}$

Pemeriksaan kehamilan sangat penting 
dilakukan oleh semua ibu hamil untuk mengetahui pertumbuhan janin dan kesehatan ibu. Hampir seluruh ibu hamil di Indonesia $(95,4 \%)$ sudah melakukan pemeriksaan kehamilan (K1) dan frekuensi kehamilan minimal 4 kali selama masa kehamilannya adalah 83,5\%. Adapun untuk cakupan pemeriksaan kehamilan pertama pada trimester pertama adalah $81,6 \%$ dan frekuensi ANC 1-12 atau K4 (minimal 1 kali pada trimester pertama, minimal 1 kali pada trimester kedua dan minimal 2 kali pada trimester 3) sebesar $70,4 \%$. Tenaga yang paling banyak memberikan pelayanan ANC adalah bidan (88\%) dan tempat pelayanan ANC paling banyak diberikan di praktek bidan $(52,5 \%) .{ }^{(7)}$

Indikator K1 ideal dan K4 pada tahun 2013 yang merujuk pada frekuensi dan periode trimester saat dilakukan ANC menunjukkan adanya keberlangsungan pemeriksaan kesehatan semasa hamil. Setiap ibu hamil yang menerima ANC pada trimester 1 (K1 ideal) seharusnya mendapat pelayanan ibu hamil secara berkelanjutan dari trimester 1 hingga trimester 3. Hal ini dapat dilihat dari indikator ANC K4. Cakupan K1 ideal secara nasioanal adalah $81,6 \%$ dengan cakupan terendah di Papua (56,3\%) dan tertinggi di Bali $(90,3 \%)$. Cakupan K4 secara nasional adalah 70,4\% dengan cakupan terendah adalah Maluku $(41,4 \%)$ dan tertinggi DI Yogyakarta $(85,5 \%)$. Selisih dari cakupan K1 dan K4 secara nasional memperlihatkan bahwa $12 \%$ dari ibu yang menerima K1 ideal tidak melanjutkan ANC sesuai standar minimal (K4). ${ }^{(7)}$

Terjadi penurunan cakupan K4 pada tahun 2013, yaitu $86,85 \%$ dan pada tahun 2016 menjadi $85,35 \%$. Tetapi, cakupan pelayanan kesehatan ibu hamil K4 tahun 2016 telah memenuhi target Rencana Strategis (Renstra) Kementerian Kesehatan sebesar 74\%. Namun demikian, terdapat 9 provinsi yang belum mencapai target tersebut yaitu, Maluku Utara, Papua, Nusa Tenggara, Papua Barat, Jambi, Maluku, Sulawesi Barat, Sulawesi Tenggara, dan DI Yogyakarta. ${ }^{(4)}$

Standar Pelayanan Minimal (SPM) adalah ketentuan tentang jenis dan mutu pelayanan dasar yang merupakan urusan wajib atau kewenangan daerah provinsi maupun kabupaten/kota yang berhak diperoleh setiap warga secara minimal. Dan juga merupakan kebutuhan dasar bagi setiap individu secara universal. Pemenuhan kebutuhan dasar dapat dipenuhi sendiri oleh warga negara atau oleh pemerintah daerah. Tanggung jawab Pemda berlaku secara nasional. ${ }^{(8)}$

Cakupan kunjungan K4 ibu hamil di Sumatera Utara meningkat dari tahun 2010 dan kemudian menurun hingga tahun 2016 dengan distribusi $83,31 \%$ pada tahun 2010 , peningkatan drastis $201388,7 \%$ dan terjadi penurunan kembali tahun 2016 84,13\%. Merujuk pada target SPM bidang kesehatan yaitu 95\% di tahun 2016, maka hanya satu kabupaten yang telah mencapai K4 sesuai SPM yaitu 95\% yaitu Kabupaten Deli Serdang $(96,84 \%)$. Tiga Kabupaten/Kota dengan cakupan K4 yang rendah adalah Kabupaten Nias Selatan yaitu (23,99\%), Kota Gunung Sitoli $(60,18 \%)$ dan Kabupaten Pakpak Bharat $(63,19 \%){ }^{(5)}$

Hasil penelitian yang dilakukan oleh Oom Komariyah tahun 2014, dengan menggunakan uji alternatif yaitu uji Fisher's Exact Test. Hasil dari uji Fisher's Exact test $\rho$ value $=0,0001<\alpha(0,05)$, maka Ho ditolak. Dengan 54 responden $(79,4 \%)$ yang memiliki dukungan keluarga baik dan patuh dalam melakukan pemeriksaan antenatal care sebesar 59 responden $(86,8 \%)$. Maka, hasil analisis penelitian menunjukkan bahwa ada hubungan yang signifikan antara Dukungan Keluarga dengan Kepatuhan Ibu Hamil Dalam Pemeriksaan Antenatal Care Di Puskesmas Banyubiru. ${ }^{(9)}$

Asuhan kehamilan mengutamakan kesinambungan pelayanan (continuity of care) sangat penting bagi wanita untuk mendapatkan pelayanan dari seorang profesional yang sama atau dari satu team tenaga profesional, sebab dengan begitu perkembangan kondisi mereka setiap saat akan terpantau dengan baik selain juga mereka menjadi lebih percaya dan terbuka karena merasa sudah mengenal si pemberi asuhan. ${ }^{(10)}$

Status sosial ekonomi merupakan suatu keadaan atau kedudukan yang diatur secara sosial dalam posisi tertentu dalam struktur masyarakat, 
pemberian posisi ini disertai pula seperangkat hak dan kewajiban yang hanya dipenuhi sipembawa statusnya, misalnya: pendapatan, pekerjaan, dan pendidikan. Status pekerjaan seseorang akan berdampak pada sosial ekonomi, hal ini berdampak pada status kesehatan, minimnya pendapatan serta pengetahuan yang didapat oleh ibu hamil. ${ }^{(11)}$

Dukungan selama masa kehamilan sangat dibutuhkan bagi seorang wanita yang sedang hamil, terutama dari orang terdekat. Seorang wanita akan merasa tenang dan nyaman dengan adanya dukungan dan perhatian dari orang-orang terdekat. Lingkungan keluarga yang harmonis ataupun lingkungan tempat tinggal yang kondusif sangat berpengaruh terhadap keadaan emosi ibu hamil. Wanita hamil sering kali mempunyai ketergantungan terhadap orang lain disekitarnya terutama pada ibu primigravida. Keluarga harus menjadi bagian dalam mempersiapkan pasangan menjadi orang tua. ${ }^{(10)}$

Keluarga merupakan unit terkecil dari masyarakat yang terdiri dari sekelompok orang yang berkumpul dan tinggal di suatu tempat di bawah satu atap dan biasanya memiliki hubungan darah atau perkawinan, dalam keadaan saling ketergantungan. Keluarga memiliki fungsi yang sangat strategis dalam mempengaruhi status kesehatan diantara anggotanya. Diantara fungsi keluarga dalam tatanan masyarakat yaitu memenuhi kebutuhan gizi dan merawat serta melindungi kesehatan para anggotanya. ${ }^{(12)}$

Pelaksanaan Antenatal Care, ibu akan semakin teratur jika mendapat dukungan besar dari keluarga. Dalam hal ini dukungan dari suami, keluarga dan masyarakat sangat berpengaruh besar terhadap keberhasilan ANC. Keluarga merupakan unit terkecil masyarakat yang terdiri atas dua orang atau lebih adanya ikatan persaudaraan atau pertalian darah, hidup dalam satu rumah tangga berinteraksi satu kebudayaan. Jadi dapat dikatakan bahwa salah satu konsep solusi untuk meningkatkan kunjungan kehamilan adalah dengan melibatkan keluarga terutama suamai dalam memberikan dukungan sehingga ibu hamil bisa patuh menjalani kunjungan kehamilan. $^{(13)}$

Hasil survei awal yang dilakukan dengan cara mewawancarai 10 ibu hamil Trimester III pada bulan September di Rumah Bersalin Dina. Dan ketika ditanya apakah keluarga mendukung pada saat akan melakukan kunjungan pemeriksaan kehamilan, 4 (40\%) ibu hamil diantaranya 1 orang ibu mendapatkan dukungan informasional, 2 orang mendapatkan dukungan instrumental dan 1 orang lagi mendapatkan dukungan emosional dari keluarga untuk melakukan kunjungan ANC. Sementara $6(60 \%)$ ibu hamil yaitu 2 diantaranya tidak mendapatkan dukungan informasional, 2 orang tidak mendapatkan dukungan penilaian, 1 orang tidak mendapatkan dukungan instrumental serta 1 orang lainnnya tidak mendapatkan dukungan emosional dari keluarganya. Dari kuesioner kepatuhan yang peneliti berikan kepada ibu, $3(30 \%)$ dari 10 orang ibu hamil patuh melakukan kunjungan ANC, dan 7 (70\%) ibu hamil tidak patuh untuk melakukan kunjungan ANC ulang.

Dari uraian diatas peneliti tertarik melakukan penelitian tentang Hubungan Dukungan Keluarga Dengan Kepatuhan Kunjungan ANC Pada Ibu Hamil Trimester III Di Rumah Bersalin Dina Kota Medan Tahun 2018.

Tujuan penelitian untuk mengetahui hubungan dukungan keluarga dengan kepatuhan kunjungan ANC pada ibu hamil trimeseter III di Rumah Bersalin Dina Kota Medan Tahun 2018.

\section{METODE}

Jenis penelitian ini adalah survei analitik adalah penelitian yang mencoba menggali bagaimana dan mengapa fenomena kesehatan itu terjadi. Penelitian ini menggunakan desain cross sectional yaitu untuk mengetahui "Hubungan Dukungan Keluarga Dengan Kepatuhan Kunjungan ANC Pada Ibu Hamil Trimester III Di Rumah Bersalin Dina Kota Medan Tahun 2018".(14)

Penelitian ini berlokasi di wilayah $\mathrm{Jl}$. Karya Gg. Bersama No. 17 yaitu Rumah Bersalin Dina Kota Medan Tahun 2018 dengan alasan masih ditemukan ibu hamil yang jarang melakukan kunjungan ulang ANC.

Populasi dalam penelitian ini adalah ibu hamil trimester III yang datang untuk 
memeriksakan kehamilan pada bulan Agustus di Rumah Bersalin Dina Kota Medan Tahun 2018 sebanyak 126 ibu hamil. Pengambilan sampel dalam penlitian ini menggunakan teknik accidental sampling yaitu pengambilan sampel secara kebetulan atau tanpa direncankan. Siapa saja yang ada ditetapkan menjadi sampel.

Alat yang digunakan untuk mengolah data yaitu program komputernya atau uji statistiknya. Teknik analisis dapat juga hanya dengan persentase, tabel, atau diagram.

Uji data primer adalah teknik pengumpulan data secara langsung oleh peneliti dengan responden atau subjek dengan cara tanya jawab sepihak secara sistematis. Data sekunder adalah data yang diperoleh dari hasil dokumentasi oleh pihak lain, data tersier adalah teknik pengumpulan data yang dilakukan peneliti yaitu dengan mencari sumber referensi yang berasal dari data WHO, Profil Kesehatan Indonesia, Profil Kesehatan Sumatera Utara, dan Jurnal-Jurnal.

Analisis univariat digunakan untuk mendeskripsikan data yang dilakukan pada tiap variabel dari hasil penelitian. Analisis bivariat digunakan Untuk mengetahui hubungan (korelasi) antara variabel bebas (independent variable) dengan variabel terikat (dependent variable). Dan analisi multivariat bertujuan untuk melihat kemaknaan hubungan antara variabel bebas dengan variabel terikat secara simultan (Uji-F) sekaligus menentukan faktor-faktor yang lebih domain berhubungan (Uji-T).

\section{HASIL}

Berdasarkan Tabel 1 diketahui bahwa dari 30 ibu hamil di Rumah Bersalin Dina Kota Medan Tahun 2018 mayoritas kategori usia antara 20-35 tahun sebanyak 18 (60\%) responden. Dari 30 responden ibu hamil tersebut dengan mayoritas kategori berpendidikan SMA 11 (36,7\%) responden, sedangkan untuk pekerjaan mayoritas sebagai Ibu Rumah Tangga sebanyak 15 (50\%) responden.

Tabel 1. Karakteristik Responden (Umur, Pendidikan, Pekerjaan) Di Rumah Bersalin Dina Kota Medan Tahun 2018.

\begin{tabular}{ccc}
\hline Karakteristik & Jumlah (N) & Persentase (\%) \\
\hline Berdasarkan Umur & 1 & 3,3 \\
$<$ 20 Tahun & 18 & 60 \\
20-35 Tahun & 11 & 36,7 \\
$>$ 35 Tahun & & \\
Berdasarkan Pendidikan & 3 & 10 \\
SD & 9 & 30 \\
SMP & 11 & 36,7 \\
SMA & 7 & 23,3 \\
Perguruan Tinggi & & \\
Berdasarkan Pekerjaan & 15 & 50 \\
IRT & 11 & 36,7 \\
Wirausaha & 4 & 13,3 \\
\hline Pegawai Swasta & &
\end{tabular}

Analisis Univariat : Berdasarkan Tabel .2. dapat diketahui bahwa distribusi frekuensi dukungan keluarga dengan kepatuhan kunjungan ANC pada ibu hamil trimester III di rumah Bersalin Dina Kota
Medan Tahun 2018. Mayoritas yang mendukung sebanyak 16 responden $(53,3 \%)$ dan tidak mendukung sebanyak 14 responden (46,7\%). Distribusi frekuensi kepatuhan kunjungan ANC pada ibu hamil Trimester III 
di Rumah Bersalin Dina Kota Medan Tahun 2018. Mayoritas yang patuh sebanyak 16 responden $(53,3 \%)$ dan tidak patuh sebanyak 14 responden $(46,7 \%)$.

Tabel 2. Distribusi Frekuensi Dukungan Keluarga Di Rumah Bersalin Dina Kota Medan Tahun 2018

\begin{tabular}{ccc}
\hline Variabel & \multicolumn{2}{c}{ Jumlah } \\
\cline { 2 - 3 } & $\mathrm{F}$ & $\%$ \\
\hline Dukungan Keluarga & 16 & 53,3 \\
Mendukung & 14 & 46,7 \\
Tidak Mendukung & & 53,3 \\
Kepatuhan & 16 & 46,7 \\
Patuh & 14 & \\
Tidak Patuh &
\end{tabular}

\section{Analisis Bivariat}

Berdasarkan Tabel 2 diatas menunjukkan bahwa dukungan keluarga informasional mempengaruhi kepatuhan ibu melakukan kunjungan ANC dari 30 responden ibu hamil Trimester III. Mayoritas Dukungan Keluarga yang mendukung sebanyak 13 responden $(43,3 \%)$ dengan yang patuh melakukan kunjungan ANC sebanyak 9 responden (30\%) dan yang tidak patuh 4 responden $(13,3 \%)$. Sedangkan dukungan keluarga yang tidak mendukung sebanyak 17 responden $(46,7 \%)$ dengan 7 responden $(23,3 \%)$ patuh dan 10 responden $(33,3 \%)$ lainnya tidak patuh

Setelah dilakukan uji statistik dengan uji Chi-Square dengan tingkat kepercayaan $95 \%$ dengan $\alpha=0,05$ bahwa nilai signifikan probabilitas dukungan keluarga informasional dengan kepatuhan kunjungan ANC pada ibu hamil trimester III adalah 0,247 atau nilai $p$ > nilai $\alpha 0,05$.

Setelah dilakukan uji statistik dengan uji Chi-Square dengan tingkat kepercayaan $95 \%$ dengan $\alpha=0,05$ bahwa nilai signifikan probabilitas dukungan keluarga penilaian dengan kepatuhan kunjungan ANC pada ibu hamil trimester III adalah 0,689 atau nilai $\mathrm{p}$ > nilai $\alpha=0,05$.

Setelah dilakukan uji statistik dengan uji Chi-Square dengan tingkat kepercayaan $95 \%$ dengan $\alpha=0,05$ bahwa nilai signifikan probabilitas dukungan keluarga instrumental dengan kepatuhan kunjungan ANC pada ibu hamil trimester III adalah 0,011 atau nilai $\mathrm{p}<$ nilai $\alpha=0,05$.

Setelah dilakukan uji statistik dengan uji Chi-Square dengan tingkat kepercayaan $95 \%$ dengan $\alpha=0,05$ bahwa nilai signifikan probabilitas dukungan keluarga emosional dengan kepatuhan kunjungan ANC pada ibu hamil trimester III adalah 0,072 atau nilai $\mathrm{p}>$ nilai $\alpha=0,05$.

Setelah dilakukan uji statistik dengan uji Chi-Square dengan tingkat kepercayaan $95 \%$ dengan $\alpha=0,05$ bahwa nilai signifikan probabilitas dukungan keluarga dengan kepatuhan kunjungan ANC pada ibu hamil trimester III adalah 0,030 atau nilai $\mathrm{p}<$ nilai $\alpha$ $=0,05$. 
Tabel .3. Tabulasi Silang Hubungan Dukungan Keluarga Informasional Dengan Kepatuhan Kunjungan ANC Pada Ibu Hamil Trimester III Di Rumah Bersalin Dina Kota Medan Tahun 2018.

\begin{tabular}{|c|c|c|c|c|c|c|c|}
\hline \multirow{3}{*}{ Variabel Bivariat } & \multicolumn{4}{|c|}{$\begin{array}{c}\text { Kepatuhan Ibu Melakukan } \\
\text { Kunjungan ANC }\end{array}$} & \multirow{2}{*}{\multicolumn{2}{|c|}{ Jumlah }} & \multirow{3}{*}{ P. Sig } \\
\hline & \multicolumn{2}{|c|}{ Patuh } & \multicolumn{2}{|c|}{ Tidak Patuh } & & & \\
\hline & $\mathrm{f}$ & $\%$ & $\mathrm{f}$ & $\%$ & $\mathrm{~N}$ & $\%$ & \\
\hline \multicolumn{8}{|c|}{ Dukungan Keluarga Informasional } \\
\hline Mendukung & 9 & 30 & 4 & 13,3 & 13 & 43,3 & \multirow{2}{*}{0,247} \\
\hline Tidak Mendukung & 7 & 23,3 & 10 & 33,3 & 17 & 56,7 & \\
\hline \multicolumn{8}{|c|}{ Dukungan Keluarga Penilaian } \\
\hline Mendukung & 5 & 16,7 & 3 & 10 & 8 & 26,7 & \multirow{2}{*}{0,689} \\
\hline Tidak Mendukung & 11 & 36,7 & 11 & 36,7 & 22 & 73,3 & \\
\hline \multicolumn{8}{|c|}{ Dukungan Keluarga Instrumental } \\
\hline Mendukung & 13 & 43,4 & 4 & 13,3 & 17 & 56,7 & \multirow{2}{*}{0,011} \\
\hline Tidak Mendukung & 3 & 10 & 10 & 33,3 & 13 & 43,3 & \\
\hline \multicolumn{8}{|c|}{ Dukungan Keluarga Emosional } \\
\hline Mendukung & 12 & 40 & 5 & 16,7 & 17 & 56,7 & \multirow{2}{*}{0,072} \\
\hline Tidak Mendukung & 4 & 13,3 & 9 & 30 & 13 & 43,3 & \\
\hline \multicolumn{8}{|l|}{ Dukungan Keluarga } \\
\hline Mendukung & 12 & 40 & 4 & 13,3 & 16 & 53,3 & \multirow{2}{*}{0,030} \\
\hline Tidak Mendukung & 4 & 13,3 & 10 & 33,3 & 14 & 46,7 & \\
\hline
\end{tabular}

Analisis Multivariat : Berdasarkan tabel Variables in the Equation diatas hanya dukungan keluarga instrumental yang nilai $\mathrm{P}$ value (Sign) $<0,25$ artinya variabel dukungan keluarga instrumental mempunyai pengaruh signifikan terhadap Y. Dukungan keluarga instrumental nilai signifikan $0,020<0,25$ sehingga dukungan keluarga instrumental memberikan pengaruh yang signifikan terhadap kepatuhan kunjungan ANC ibu hamil trimester III.

Besarnya pengaruh ditunjukkan dengan nilai $\operatorname{Exp}(\mathrm{B})$ atau disebut juga OODS RATIO (OR). Variabel dukungan keluarga instrumental dengan Exp (B) yaitu 11.208 maka dukungan keluarga instrumental 11 kali mempengaruhi kepatuhan kunjungan ANC pada ibu hamil trimester III. Nilai $\mathrm{B}=$ Logaritma Natural dari $5.976=2.417$.

Tabel 3. Hubungan Dukungan Keluarga Dengan Kepatuhan Kunjungan ANC Pada Ibu Trimester III Di Rumah Bersalin Dina Kota Medan Tahun 2018.

Variables in the Equation

\begin{tabular}{|c|c|c|c|c|c|c|c|c|}
\hline & \multirow{2}{*}{ B } & \multirow{2}{*}{ S.E } & \multirow{2}{*}{ Wald } & \multirow{2}{*}{ df } & \multirow{2}{*}{ Sig. } & \multirow{2}{*}{$\operatorname{Exp}(B)$} & \multicolumn{2}{|c|}{ 95\% C.I for EXP (B) } \\
\hline & & & & & & & Lower & Upper \\
\hline $\begin{array}{l}\text { Step } 1^{\mathrm{a}} \\
\text { Kat_Dukungan Informasional }\end{array}$ & -.535 & 1.145 & .218 & 1 & .641 & .586 & .062 & 5.530 \\
\hline Kat_Dukungan Penilaian & -.236 & 1.115 & .045 & 1 & .832 & .790 & .089 & 7.017 \\
\hline Kat_Dukungan Instrumental & 2.417 & 1.041 & 5.385 & 1 & .020 & 11.208 & 1.456 & 86.290 \\
\hline Kat_Dukungan Emosional & 1.583 & 1.007 & 2.472 & 1 & .116 & 4.870 & .677 & 35.055 \\
\hline Constant & -1.818 & .857 & 4.500 & 1 & .034 & .162 & & \\
\hline
\end{tabular}


PEMBAHASAN

\section{Hubungan Dukungan Keluarga dengan Kepatuhan Kunjungan ANC}

Berdasarkan hasil analisis bivariat dari 30 responden (100\%), yang mendapatkan dukungan keluarga sebanyak 16 responden $(53,3 \%)$ dan 14 responden $(46,7 \%)$ tidak mendapat dukungan keluarga. Selanjutnya setelah dilakukan uji statistik menggunakan uji Chi-Square dengan tingkat kepercayaan 95\% dengan $\alpha=0,05$ bahwa nilai signifikan probabilitas variabel dukungan keluarga dengan kepatuhan kunjungan ANC di Rumah Bersalin Dina Kota Medan Tahun 2017 bahwa nilai probabilitasnya yaitu $0,030>$ nilai $\alpha=0,05$. Hasil analisis ini tidak memenuhi kriteria persyaratan hipotesis hubungan, sehingga dapat disimpulkan bahwa dukungan keluarga informasional memiliki hubungan dengan kepatuhan kunjungan ANC. Menurut Friedman, dukungan keluarga adalah sebagai suatu proses hubungan antara keluarga dengan lingkungan sosial. Dalam semua tahap, dukungan sosial keluarga mampu berfungsi dengan berbagai kepandaian dan akal, sehingga akan meningkatkan kesehatan dan adaptasi mereka dalam kehidupan ${ }^{(9)}$.

Pada setiap tahap usia kehamilan, ibu akan mengalami perubahan baik yang berisfat fisik maupun psikologis. Ibu harus melakukan adaptasi pada setiap perubahan yang terjadi, dimana sumber stress terbesar terjadi karena sedang melakukan adaptasi terhadap kondisi tertentu. Dalam menjalani proses ini, ibu hamil hamil sangat membutuhkan dukungan yang intensif dari keluarga, dengan cara menunjukkan perhatian dan kasih sayang. ${ }^{(15)}$

Hal ini sejalan dengan penelitian yang dilakukan oleh Erlina Puspitaloka Mahadewi dan Maftuhatun Nadriroh bahwa dari dari 54 responden masih banyak ibu hamil yang memiliki dukungan keluarga tidak baik (50\%), 22 orang diantaranya tidak patuh melakukan kunjungan ANC dan 5 orang patuh. Selanjutnya 27 orang responden memiliki dukungan keluarga baik (50\%), 14 orang patuh melakukan kunjungan ANC dan 13 orang lainnya tidak patuh melakukan kunjungan ANC. ${ }^{(16)}$
Hasil penelitian ini mirip dengan penelitian yang dilakukan oleh Simanjuntak (2002) menunjukkan bahwa ada hubungan yang bermakna antara dukungan suami/keluarga dengan kunjungan $\mathrm{K} 4$, dimana diperoleh $\mathrm{OR}=$ 2, 89 yang berarti bahwa responden yang memperoleh dukungan baik mempunyai kecenderungan untuk melakukan kunjungan K4 sesuai standar 3 kali lebih besar dibandingkan responden yang kurang mendapat dukungan suami/keluarga. ${ }^{(12)}$

Penelitian ini sejalan dengan yang dilakukan oleh Fitrayeni,Suryati, Rizki Mela Faranti (2015) bahwa dukungan sosial dari orang-orang yang berarti bagi individu, seperti: keluarga, pasangan hidup, teman dekat, saudara, dan tetangga. Dukungan keluarga berperan penting dalam terwujudnya hal yang positif. Untuk itu diperlukan peningkatan edukasi bagi suami, sehingga kebutuhan ibu hamil untuk melaksanakan kunjungan ANC dengan baik dan lengkap dapat tercapai. ${ }^{(17)}$

Peneliti menemukan masih terdapat ibu hamil yang memiliki kurangnya keluarga yang mendukung untuk ibu melakukan pemeriksaan kunjungan kehamilan, seperti kurangnya memberikan kenyamanan ibu di dalam rumah karena keluarga yang terlalu sibuk dengan pekerjaannya masing-masing, kurangnya perhatian keluarga terhadap kehamilan ibu dan janin dikandungannya sehingga ibu enggan untuk berkeluh kesah kepada keluarga mengenai permasalahan yang dihadapinya, keluarga yang tidak memberikan informasi seputar kehamilan sehingga ibu tidak mengetahui betapa bermanfaatnya melakukan kunjungan pemeriksaan kehamilan secara rutin.

Hasil dari penelitian bahwa dari keempat variabel dukungan keluarga tersebut yaitu dukungan keluarga informasional, penilaian, instrumental dan emosional hanya satu variabel yang membuktikan bahwa ada hubungan dukungan keluarga dengan kepatuhan kunjungan ANC pada ibu hamil trimester III yaitu variabel dukungan keluarga instrumental, dimana nilai signifikannya $0,011<0,05$.

Berdasarkan Model Summary nilai Nagelkerke R Square sebesar 0,424 dan Cox \& 
Snell R Square sebesar 0,317 yang menunjukkan bahwa kemampuan variabel independen dalam menjelaskan variabel dependen adalah sebesar 0,424 atau $42,4 \%$ dan terdapat $100 \%-42,4 \%=57,6 \%$ faktor lain di luar model yang menjelaskan variabel dependen.

Berdasarkan tabel Classification Table di atas, jumlah sampel yang patuh melakukan kunjungan ANC sebanyak $13+3=16$ orang, yang patuh melakukan kunjungan ANC sebanyak 13 orang dan yang patuh melakukan kunjungan ANC tetapi tidak patuh melakukan kunjungan ANC sebanyak 3 orang. Jumlah sempel yang tidak patuh melakukan kunjungan ANC sebanayak $11+3=14$ orang, yang tidak patuh melakukan kunjungan ANC sebanayak 11 orang dan tidak patuh melakukan kunjungan ANC tetapi patuh melakukan kunjungan ANC sebanyak 3 orang. Tabel diatas memberikan nilai overall percentage sebesar $(13+11) / 30=$ 0,8 yang berarti ketepatan model penelitian ini tinggi yaitu sebesar $80 \%$.

Berdasarkan tabel Variables in the Equation diatas hanya dukungan keluarga instrumental yang nilai $\mathrm{P}$ value $($ Sign $)<0,25$ artinya variabel dukungan keluarga instrumental mempunyai pengaruh signifikan terhadap $\mathrm{Y}$. Dukungan keluarga instrumental nilai signifikan $0,020<0,25$ sehingga dukungan keluarga instrumental memberikan pengaruh yang signifikan terhadap kepatuhan kunjungan ANC ibu hamil trimester III. Oleh karena itu nilai B bernilai positif, maka dukungan keluarga instrumental mempunyai hubungan positif dengan kepatuhan kujungan anc ibu hamil trimester III.

Pemeriksaan kehamilan merupakan salah satu tahapan penting menuju kehamilan yang sehat. Boleh dikatakan pemeriksaan kehamialn merupakan hal yang wajib dilakukan oleh para ibu hamil. Pemeriksaan kehamilan dapat dilakukan melalui dokter kandungan atau bidan dengan minimal pemeriksaan 3 kali selama kehamilan, yaitu pada usia kehamilan trimester pertama, trimester kedua, dan trimester ketiga, itupun jika kehamilan normal. Namun ada baiknya jika kehamilan dilakukan sebulan sekali hingga usia 6 bulan, sebulan dua kali pada usia 7-8 bulan, dan seminggu sekali ketika usia kandungan menginjak 9 bulan. ${ }^{(18)}$

Dukungan keluarga adalah sebagai suatu proses hubungan dukungan keluarga dengan lingkungan sosial. Dalam semua tahap, dukungan sosial keluarga mampu berfungsi dengan berbagai kepandaian dan akal, sehingga akan meningkatkan kesehatan dan adaptasi mereka dalam kehidupan. ${ }^{(10)}$

Kepatuhan adalah sejauh mana perilaku pasien sesuai dengan ketentuan yang diberikan oleh professional kesehatan. Kepatuhan kunjungan Antenatal Care (ANC) dapat diartikan sebagai ketaatan dalam kunjungan ke tempat pelayanan kesehatan oleh ibu hamil sesuai dengan saran petugas kesehatan yaitu bidan atau dokter spesialis sesuai dengan standar Antental Care (ANC) yang ditetapkan. ${ }^{(19)}$

Menurut Teori Snehendu B. Kar (Notoatmodjo, 2003) menyimpulkan bahwa perilaku kesehatan seseorang ditentukan antara lain oleh ada atau tidaknya dukungan masyarakat sekitarnya (social support). Orang yang tinggal dilingkungan yang menjunjung tinggi aspek kesehatan akan lebih antusias dalam menjaga kesehatannya. Sebaliknya mereka yang tinggal dilingkungan dengan pola hidup tidak sehat/tidak memperhatikan kesehatan akan cenderung tidak perduli dengan pencegahan penyakit atau pemeriksan kesehatan secara teratur. ${ }^{(12)}$

Kunjungan ANC yang teratur dan pengawasan yang rutin dari bidan maupun dokter selama masa kehamilan diharapkan komplikasi yang mungkin terjadi selama hamil, termasuk riwayat penyakit secara umum dapat dikenali lebih dini. Hal ini dapat mengurangi resiko kematian ibu hamil. ${ }^{(20)}$

Berdasarkan hasil penelitian Fina Andriana, dengan hasil uji statistic correlation dengan tingkat kepercayan $95 \%$ dan nilai $\alpha=$ 0,05 maka dapat diketahui nilai $\rho=0,04<\alpha=$ 0,05 maka dapat disimpulkan Ha diterima, yang artinya ada Hubungan Dukungan Keluarga Dengan Kepatuhan Ibu Melakukan Pemeriksaan 
Antenatal Cara pada Trimester III di Puskesmas Simeule Timur Tahun 2017. ${ }^{(21)}$

Hasil penelitian ini sesuai dengan penelitian oleh Ni Nyoman Mestri Agustini bahwa terdapat hubungan tingkat pengetahuan ibu dan dukungan keluarga dengan cakupan pelayanan ANC. Ibu hamil yang tidak mendapatkan dukungan keluarga 2,54 kali berisiko melakukan kunjungan ANC tidak lengkap dibanding ibu yang mendapat dukungan keluarga. ${ }^{(17)}$

Penelitian ini sejalan yang dilakukan dengan Nurul Ika Sulistiyowati (2017) bahwa wanita hamil tidak hidup sendiri tetapi dalam lingkungan keluarga dan budaya yang kompleks. Pada kenyataanya peranan suami dan keluarga sangat besar bagi ibu hamil dalam mendukung perilaku atau tindakan ibu hamil dalam memanfaatkan pelayanan kesehatan. ${ }^{(13)}$

Hal ini sejalan dengan penelitian yang dilakukan oleh Oom Komariyah dengan jumlah sampel 68 orang. Penelitian menggunakan uji Fisher's Exact Test p-value $=0,0001<\alpha(0,05)$. Hasil penelitian menunjukkan antara dukungan keluarga dengan kepatuhan ibu dalam pemeriksaan antenatal care ada hubungan. Hasil penelitian pada dukungan instrumental sebanyak 43 responden $(63,2 \%)$ menjawab keluarga pernah membicarakan tentang rencana tempat untuk persalinan, bearti dalam hal ini keluarga dapat membantu menyediakan apa yang nantinya dipersiapkan dalam proses persalinan. Hal ini ditunjukkan dengan adanya persiapan alat transportasi untuk mengantar memerikskan kehamilan serta mempersiapkan perlengkapan pada calon bayi yang akan lahir. ${ }^{(9)}$

\section{SIMPULAN}

Kesimpulan penelitian adalah ada Hubungan Dukungan Keluarga dengan Kepatuhan Kunjungan ANC pada ibu hamil Trimester III. Variabel yang paling signifikan adalah Dukungan Keluarga Instrumental.

\section{UCAPAN TERIMA KASIH}

Terima kasih kepada Ibu Dina, Am.Keb selaku bidan di Rumah Bersalin Dina yang telah memberikan izin untuk melakukan penelitian dan juga menerima peneliti dengan baik selama dalam melakukan penelitian.

\section{DAFTAR RUJUKAN}

1. Dewi S, Putri K, Christiani N, Nirmasari C. Hubungan Usia Ibu Hamil Dengan Kepatuahn ANC Di Puskesmas Suruh Kabupaten Semarang. 2013;33-41.

2. Ardillah S, Sanusi SR. Hubungan Pengetahuan Dan Sikap Terhadap Tindakan Ibu Hamil Tentang Deteksi Dini Tanda-Tanda Bahaya Kehamilan Di Puskesmas Medan Deli Tahun 2015. 2015;

3. World Health Organization. World Health Statistics. 2017;

4. Kesehatan K, Indonesia R. Profil Kesehatan Indonesia. 2016.

5. Dinas Kesehatan Provinsi Sumatera Utara. Profil Kesehatan Provinsi Sumatera Utara. 2016;

6. Rahman A. Hubungan Pengetahuan Dan Sikap Ibu Hamil Dalam Mengenal Tanda Bahaya Kehamilan Dan Persalinan Di Puskesmas Managaisaki. 2015;1(2):43-51.

7. Badan Penelitian dan Pengembangan Kesehatan. Riset Kesehatan Dasar (RISKESDAS) 2013. Lap Nas 2013. 2013;1-384.

8. Sehat I, Pendekatan D. Standar Pelayanan Minimal (SPM), Kementerian Kesehatan Republik Indonesia. 2017;

9. Komariyah O. Hubungan Antara Dukungan Keluarga Dengan Kepatuhan Ibu Hamil Dalam Pemeriksaan Antenatal Care Di Puskesmas Banyu Biru Kabupaten Semarang. Kebidanan. 2014;

10. Walyani ES. Asuhan Kebidanan Pada kehamilan. 1st ed. Yogyakarta: Pustaka Baru Press; 2015.

11. Tahun K, Susanto J, Ode L, Imran A, Cece A. Kunjungan 1 - Kunjungan 4 ( K1 - K4 ) Pada Ibu Hamil Di RSUD Kota. Kesehat Masy. 2016;4:1-7.

12. Care A, Indriyanti K, Sari P, Efendy HV. Jurnal Keperawatan dan Kebidanan. 2013;93-113.

13. Sulistiyowati NI. Hubungan Dukungan Keluarga Dengan Kepatuhan Ibu Dalam Kunjungan Kehamilan Di Desa Dlangu. ilmu Keperawatan. 2017;1-11.

14. Muhammad I. Panduan Penyusunan Karya Tulis Ilmiah Bidang Kesehatan Menggunakan Metode Ilmiah. 6th ed. Bandung: Citapustaka Media Perintis; 
2016.

15. Rukiah AY, Lia Y. Asuhan Kebidanan Kehamilan Berdasarkan Kurikulum Berbasis Kompetensi. 1st ed. Jakarta: Trans Info Media; 2014.

16. Mahadewi EP, Nadrihoh M. Hubungan Pengetahuan Tentang Tanda Bahaya Kehamilan dan Dukungan keluarga Dengan Kepatuhan Kunjungan Antenatal Care (ANC) Pada Ibu Hamil Trimester III Di Puskesmas Ciruas Kabupaten Serang. Kesehat Masy. 2016;

17. Fitrayeni, Suryati, Faranti RM. Penyebab Rendahnya Kelengkapan Kunjungan Antenatal Care Ibu Hamil Di Wilayah Kerja Puskesmas Pegambiran. 2015;1017.

18. Hutahaean S. Perawatan Antenatal. Jakarta: Salemba Medika; 2013.

19. Hardiani, Purwanti RS, Agustin.

Motivasi Dan Kepatuhan Kunjungan Antenatal Care (ANC) Pada Ibu Hamil Trimester III. Keperawatan. 2012;3(2):183-8.

20. Care A, Pada ANC, Hamil IBU, Tabanan DIK. Hubungan dukungan suami dengan kunjungan antenatal care (anc) pada ibu hamil di kabupaten tabanan. 2014; 